\title{
Diversity of the herbaceous layer in mixed bushveld
}

\author{
WERNER G. DÖRGELOH
}

Author is a wildlife biologist, Applied Natural Sciences, Technikon SA, Private Bag X6, Florida, 1710, South Africa.e-mail: wdorgelo@tsamail.trsa.ac.za

\begin{abstract}
The diversity of the herbaceous layer in the Nylsvley Nature Reserve (Mixed Bushveld) was investigated to enhance the understanding of savanna ecosystems and to serve as a baseline for future monitoring to facilitate management. Species composition and density, dry weight contribution per species, and grass density was measured with a small-quadrat method. A total of $\mathbf{7 3}$ grass species were recorded. Plant communities were compared in terms of percentage composition and percentage dry weight per ecological group, species diversity and grass density with general linear modeling. The herbaceous layer of most plant communities consisted predominantly of increaser I species (increasing in under-utilized areas), with increaser I and decreaser species (decreasing with under or over-utilization) producing the highest biomass. The dominance of increaser III species (becoming dominant in heavily over-grazed areas) in the Sporobolus ioclados -Acacia tortilis Savanna indicates previous over-utilization of this plant community. A generally high species diversity (Simpson's index 1-D >0.72) in the reserve is influenced by environmental factors and is a reflection of previous low animal stocking densities and a rotational burning regime. Grass density varied from 53.07 to 219.13 grasses/ $\mathrm{m}^{-2}$. A negative correlation $(r=-0.6654)$ between grass density and species density supports the principle that species diversity is reduced in over-grazed areas. The high diversity of the herbaceous layer in the Nylsvley Nature Reserve may serve as a benchmark for comparing range diversity over time and space within this vegetation type.
\end{abstract}

Key Words: species composition, species density, species diversity, percentage dry weight, grass density, Simpson's index, bootstrapping

The herbaceous layer composition is changing continuously in space and time due to a combination of factors, such as grazing, fire, and rainfall which differ in intensity, duration, and timing. O'Connor (1991) found that rainfall variability over 1 or 2 years could induce substantial changes in composition. Composition is further affected by grazing. Tuft survival of grass species decreased by approximately $48 \%$ under rainfall interception and grazing experiments $\left(\mathrm{O}^{\prime}\right.$ Connor

Research was funded by the Foundation for Research Development and partly by Technikon SA. Environmental Affairs Northern Province gave permission to conduct the study in the Nylsvley Nature Reserves.

Manuscript accepted 29 Nov. 1998.

\section{Resumen}

Se investigó la diversidad del estrato herbáceo en la Reserva Natural Nylsvley (Mixed Bushveld) para aumentar el entendimiento de los ecosistemas de savana, que sirva de referencia para futuras comparaciones y facilitar el manejo. La composición y densidad de las especies, la contribución del peso seco por especie y la densidad de pasto fueron medidas con el método del cuadrante pequeño. Se registraron un total de 73 especies de pastos. Las comunidades de plantas se compararon en términos de porcentaje de composición y peso seco por grupo ecológico, diversidad de especies y densidad de pastos la comparacion se hizó mediante modelos lineales generales. El estrato herbáceo de la mayoría de las comunidades de plantas consistió principalmente de especies incresoras I (que aumentan en áreas subutilizadas), las especies incresoras I y decresoras (que disminuyen con sub o sobreutilización) produjeron la mayor cantidad de biomasa. La dominancia de especies incresoras III (dominantes en áreas fuertemente sobreutlizadas) en la savana de Isporobolus iocladosy-Acacia tortilis indican una sobreutilización previa de esta comunidad. La alta diversidad de especies (Indice de Simpson 1-D>0.72) de la reserva esta influenciada por factores ambientales y también es un reflejo de la baja densidad de carga animal anterior y un régimen rotacional de quemas. La densidad de pasto vario de 53.07 a 219.13 pastos $\mathrm{m}^{-2}$. Una correlación negativa $(r=\mathbf{- 0 . 6 6 5 4})$ entre los pastos y la densidad de especies refuerza el principio de que la diversidad de especies es reducida en áreas sobreutilizadas. La alta diversidad del estrato herbáceo en la reserva natural de Nylsvley puede servir como una referencia para comparar el rango de diversidad a través del tiempo y el espacio dentro de este tipo de vegetación.

1991). The high species diversity in the Nylsvley Nature Reserve is attributable to the diversity of habitats, the climatic, geomorphological and biogeographical history of the region, and the long period of uninterrupted, evolutionary development (Scholes and Walker 1993).

When only a sample of species in the community is obtained, it is necessary to distinguish between numerical species richness, that is number of species per specified number of individuals or biomass, and species density, that is number of species per specified collection area (Magurran 1991). Species evenness or equitability refers to how equally abundances (number of individuals, biomass and cover) are distributed among species (Goldsmith et al. 1986, Ludwig and 
Reynolds 1988, Morrison et al. 1992). Diversity indices combine both species richness and evenness into a single value (Ludwig and Reynolds 1988, Magurran 1991) and are therefore more suitable for analysis of community structure. These are also called heterogeneity indices (Ludwig and Reynolds 1988). The advantage of diversity indices is that no assumptions about distribution of individuals among species have to be made (Morrison et al. 1992), and they are therefore referred to as non-parametric indices (Magurran 1991). Although the greatest problem with diversity indices is interpretation of their values, they are widely applied in community analyses (Ludwig and Reynolds 1988, Magurran 1991, Morrison et al. 1992). These indices merely reflect community structure by changing with species richness, equitability and sometimes density (Morrison et al. 1992). Simpson's index (D) is commonly used (Magurran 1991) and is based on probability theory (Goldsmith et al. 1986). It measures the probability that 2 individuals selected at random from a sample belong to different species. Simpson's index is most sensitive to changes in common species (Magurran 1991, Morrison et al. 1992). Abundance or density of grasses is defined as number of individuals of a particular species per unit area (Goldsmith et al. 1986, Causton 1988, Goldsmith 1991) which is related to biomass. For the same height, grass quantity varies according to the density (Voisin 1988).

In the late 1970s and 1980s alpha diversity (number of species in a defined area) was measured only in the Eragrostis pallens-Burkea africana savanna as part of the Savanna Biome Programme. An alpha diversity of 319 plant species was high by global standards of 80 to 100 species $0.1 \mathrm{ha}^{-1}$. Disturbed areas with fertile soils within this plant community had a diversity of 40 to 60 species $0.1 \mathrm{ha}^{-1}$ (Scholes and Walker 1993). However no work has been published on the herbaceous diversity of the entire Nylsvley Nature Reserve. A more in-depth knowledge of the diversity of the herbaceous layer can serve as a benchmark for future monitoring which would facilitate management. Objectives of this study were to estimate and compare percentage composition and percentage dry weight per ecological group, species density and diversity and grass density between plant communities.

\section{Materials and Methods}

The study was conducted in the Nylsvley Nature Reserve (2439'S $\left.28^{\circ} 42^{\prime} \mathrm{E}\right)$, South Africa, situated in Mixed Bushveld on the border between a moist and dry savanna (Acocks 1988). The rainy season in summer (maximum mean daily temperature of $29.3^{\circ} \mathrm{C}$ ) is followed by dry, cold winters (minimum mean daily temperature of $6.1^{\circ} \mathrm{C}$ ). In the $1993 / 1994$ and $1994 / 1995$ rainy seasons, a rainfall of $480.5 \mathrm{~mm}$ and 512.4 $\mathrm{mm}$, respectively was lower than the long-term rainfall of $623 \mathrm{~mm}$ (standard deviation of $134 \mathrm{~mm}$ ) (Scholes and Walker 1993). Vegetation surveys were conducted in 8 plant communities, identified from a vegetation map constructed by Coetzee et al. (1976), Frost (1987), and Scholes and Walker (1993):

1. Rhus leptodictya-Combretum apiculatum Variation (lithosols underlain by rock)

2. Cymbopogon plurinodis-Combretum apiculatum Variation (lithosols underlain by rock)

3. Eragrostis nindensis-Digitaria monodactyla Variation (lithosols underlain by rock)

4. Sporobolus ioclados-Acacia tortilis Savanna (fine-textured illuvial soils with high clay contents)

5. Nyl River and floodplain (alluvial soils)

6. Aristida bipartita-Setaria sphacelata Savanna variation (vertisols and mollisols)

7. Aristida bipartita-Setaria sphacelata Grassland variation (vertisols and mollisols)

8. Eragrostis pallens-Burkea africana Savanna (well-drained, residual sandy soils)

\section{Sampling}

Snyman et al. (1990) suggested the dry-weight rank method, a smallquadrat method, and the comparative yield method to estimate herbaceous composition and phytomass, respectively of the semi-arid savanna of the Northern Province. In each plant community 3 sites were surveyed in February/March 1995. A stratified, nonrandom sampling approach was fol- lowed where, at each site, 20 quadrats $\left(0.25 \mathrm{~m}^{2}\right)$ were placed $5 \mathrm{~m}$ apart on a single line transect (Dörgeloh 1997), assuming independence between sampling points.

\section{Grass density}

Each rooted herbaceous plant within a $0.25 \mathrm{~m}^{2}$ square was counted. Density estimates were based on a convenient morphological unit. In this case each rooted aerial shoot was treated as a unit. It is almost impossible to determine the density of grass species which spread vegetatively (Goldsmith et al. 1986). Therefore rooted nodes of stolons of rhizomatic grasses and parts of tufts, that had split and were at least 2 centimetres from the nearest other plant of the same species, were counted as individuals. This was applied to all monocarpic (annuals and biennials) and polycarpic (perennials) species which usually have extensive below ground vegetative growth systems (Causton 1988).

\section{Species composition and density}

Each rooted grass species within a $0.25 \mathrm{~m}^{2}$ square was identified according to Gibbs Russell et al. (1991) and Van Oudtshoorn (1992). Forbs as a group $(\approx 15$ species) was treated as a single species. Species density is the most commonly used measure of species richness (number of species) (Magurran 1991) and was calculated from the number of species per $15 \mathrm{~m}^{2}$ for each plant community.

\section{Biomass contribution per species}

The relative biomass contribution of grass species was estimated with the dry-weight rank method, as developed by 't Mannetje and Haydock (1963) and described by Kelly and McNeill (1980), Barnes et al. (1982), Ben-Shahar (1991) and Shackleton (1992). Each of the 3 most dominant grass species or forb in a square was ranked according to its relative biomass contribution.

\section{Data analysis}

The hypotheses tested were that no differences existed between plant communities in terms of percentage composition and percentage dry weight per ecological group, species diversity, and grass density. Grass species were grouped into 4 ecological groups based on their response to grazing as described 
by Tainton (1984), Holechek et al. (1989), Snyman et al. (1990) and Van Oudtshoorn (1992). These were decreasers, that is species decreasing with over or under-utilization, increaser I, species increasing in under-utilized areas, and increaser II and increaser III species becoming dominant in moderate and heavily over-grazed areas, respectively. Species were grouped into ecological groups as described above.

Herbage mass of each ranked species was calculated using the multipliers proposed by 't Mannetje and Haydock (1963). Barnes et al. (1982) derived their own multipliers but these did not increase the precision of estimates significantly. They therefore recommended the use of multipliers of " $t$ Mannetje and Haydock (1963).

Data of 3 sites was pooled for each plant community as suggested by Wratten and Fry (1980). Species diversity was calculated with Simpson's index (D) using absolute species abundances. This index measures the probability that 2 individuals selected at random from a sample belong to different species. Therefore if the probability is high that both individuals belong to the same species, the diversity of the community is low. Because diversity decreases as D increases, Simpson's index is usually expressed as 1-D (Magurran 1991). The equation of Simpson's index described by (Wratten and Fry 1980, Goldsmith et al. 1986, Ludwig and Reynolds 1988, Magurran 1991, Morrison et al. 1992, Shukla and Srivastava 1992) is:

$$
\mathrm{D}=1-\sum\left\{\left[\mathrm{n}_{\mathrm{i}}\left(\mathrm{n}_{\mathrm{i}}-1\right)\right] /[\mathrm{N}(\mathrm{N}-1)]\right\}
$$

where $\mathrm{D}=$ diversity index

$\mathrm{n}_{\mathrm{i}}=$ number of individuals of species $i$

$\mathrm{N}=$ total number of individuals of all species in the sample

Simpson's index value varies from 0 to 1 . Low diversity $(\mathrm{D}=0)$ occurs when each individual belongs to the same species and maximum diversity $(\mathrm{D}=1)$ describes a community in which each individual belongs to a different species (Ludwig and Reynolds 1988).

Since an index gives only 1 value per area, it is not possible to test variation and statistical differences in species diversity among plant communities. To overcome this problem, bootstrapping or jacknifing techniques can be applied (Krebs 1989). These techniques are also used to estimate accuracy of ecological indices (Dixon 1993). The data set of each plant community was bootstrapped separately where 10,000 iterations, based on number and distribution of species, were selected randomly. A Simpson's index value was calculated for each of these iterations. Paired tests of these data sets were then conducted between different combinations of plant communities. The bias of the bootstrap estimate of the mean was calculated as:

$$
\operatorname{Bias}\left(\overline{\mathrm{x}}_{\mathrm{S}}\right)=\overline{\mathrm{x}}_{\mathrm{B}}-\overline{\mathrm{x}}_{\mathrm{S}}
$$

where $\overline{\mathrm{X}}_{\mathrm{B}}=$ bootstrap estimate of the mean

$\overline{\mathrm{x}}_{\mathrm{S}}=$ observed mean of the original sample (Krebs 1989)

Differences in percentage composition and percentage dry weight per ecological group, species diversity and grass density were tested with general linear modeling (SAS Inc. 1990) at a $95 \%$ confidence level.

\section{Results}

\section{Percentage species composition and percentage dry weight per ecological group}

Statistical analyses showed similarities among plant communities in terms of percentage species composition $(\mathrm{p}=$ $1.0)$ or percentage dry weight of ecological groups $(\mathrm{p}=1.0)$. Most plant communities had a large percentage of increaser I grasses, with increaser I and decreaser grasses producing the largest dry weight (Table 1). Only Sporobolus ioclados-Acacia tortilis Savanna consisted predominantly of increaser III grasses in terms of percentage composition and percentage dry-weight (Table 1). The large percentage of increaser II in the Eragrostis pallens-Burkea africana Savanna was mainly the result of 1 species, Digitaria eriantha Steud. (Finger grass).

In terms of percentage composition and percentage dry weight Setaria sphacelata Schumach. (Common bristle grass) was dominant in plant communities on lithosols (1, 2, and 3). and Sporobolus ioclados Nees (Pan dropseed) in the Sporobolus iocladosAcacia tortilis Savanna. In the Nyl floodplain Leersia hexandra Swartz (percentage composition) and Panicum

\begin{tabular}{|c|c|c|c|c|c|c|c|}
\hline Plant community & & DECR. & INC. I & INC. II & INC. III & $\begin{array}{c}\text { STATUS } \\
\text { UNKNOWN }\end{array}$ & FORBS \\
\hline Rhus leptodictya - & $\% \mathrm{C}$ & 12.77 & 32.49 & 17.57 & 12.11 & & 24.88 \\
\hline Combretum apiculatum Variation & $\% \mathrm{DW}$ & 13.79 & 36.70 & 41.03 & 7.22 & & 2.29 \\
\hline Cymbopogon plurinodis - & $\% \mathrm{C}$ & 8.61 & 54.42 & 14.49 & 3.13 & & 18.59 \\
\hline Combretum apiculatum Variation & $\% \mathrm{DW}$ & 11.22 & 70.26 & 9.74 & 4.88 & & 3.97 \\
\hline Eragrostis nindensis- & $\% \mathrm{C}$ & 8.23 & 51.93 & 17.91 & 3.62 & & 17.89 \\
\hline Digitaria monodactyla Variation & $\% \mathrm{DW}$ & 14.69 & 58.47 & 18.67 & 2.37 & & 6.67 \\
\hline Sporobolus ioclados - & $\% \mathrm{C}$ & 1.22 & 0.00 & 21.20 & 45.81 & 1.19 & 30.57 \\
\hline Acacia tortilis Savanna & $\% \mathrm{DW}$ & 0.42 & 0.00 & 11.74 & 54.74 & 2.08 & 31.60 \\
\hline \multirow[t]{2}{*}{ Nyl River and floodplain } & $\% \mathrm{C}$ & 16.88 & 13.62 & 0.00 & 53.11 & & 16.24 \\
\hline & $\% \mathrm{DW}$ & 77.37 & 13.06 & 0.00 & 17.51 & & 8.96 \\
\hline Aristida bipartita-Setaria & $\% \mathrm{C}$ & 20.49 & 58.72 & 0.69 & 2.58 & 1.42 & 15.60 \\
\hline sphacelata Savanna Variation & $\% \mathrm{DW}$ & 48.67 & 40.87 & 0.42 & 3.60 & 4.27 & 1.66 \\
\hline Aristida bipartita-Setaria & $\% \mathrm{C}$ & 33.04 & 30.15 & 6.79 & 3.57 & 6.78 & 12.82 \\
\hline sphacelata Grassland Variation & $\% \mathrm{DW}$ & 71.80 & 11.73 & 5.21 & 0.17 & 0.00 & 12.09 \\
\hline Eragrostis pallens - & $\% \mathrm{C}$ & 19.48 & 1.38 & 51.65 & 5.65 & & 21.86 \\
\hline Burkea africana Savanna & $\% \mathrm{DW}$ & 23.72 & 3.80 & 59.83 & 5.82 & & 6.84 \\
\hline
\end{tabular}

Table 1. Total percentage composition (\% $\mathrm{C})$ and percentage dry-weight (\%DW) of each ecological group and plant community. 
schinzii (percentage dry weight) were dominant. Ischaemum afrum Dandy (Turf grass) and Themeda triandra Forssk. (Red grass) were dominant in both Aristida bipartita-Setaria sphacelata plant communities (6 and 7) and $D$. eriantha (percentage composition) and Eragrostis pallens Hack. (Broom love grass) (percentage dry weight) in the Eragrostis pallens- Burkea africana Savanna. In most plant communities the large number of forbs had a low percentage dry weight (Table 1), except for Sporobolus ioclados-Acacia tortilis Savanna where it also had a large percentage dry weight.

\section{Species density}

A total of 73 grass species, including forbs as a group was recorded. Species density (species $/ 15 \mathrm{~m}^{2}$ ) was highest in plant communities on lithosols (1,2, and 3 ) and lowest in the Sporobolus ioclados-Acacia tortilis Savanna and $\mathrm{Nyl}$ floodplain (Table 2).

\section{Species diversity}

Statistical tests of bootstrapped data based on species occurrence and eveness indicated no significant differences $(\mathrm{t}<1.96)$ in species diversity among all plant communities. Species diversity of all plant communities was relatively high (1-D > 0.72) (Table 2). High index values of 3 plant communities on the lithosols $(1,2$, and 3$)$ indicate an even distribution of individuals among a large number of species. Fewer species and a less even distribution of abundances among species were found in the Sporobolus ioclados-Acacia tortilis Savanna and the Aristida bipartitaSetaria sphacelata Savanna Variation (Table 2).

\section{Grass density}

Grass density differed among plant communities $(\mathrm{p}<0.05)$. The high grass densities in the Sporobolus iocladosAcacia tortilis Savanna and the Aristida bipartita-Setaria sphacelata plant communities (6 and 7) (Table 2) differed significantly $(\mathrm{p}<0.05)$ from one another and from plant communities on lithosols $(1,2$, and 3$)$. Grass densities in the Nyl floodplain differed from the Sporobolus ioclados-Acacia tortilis Savanna and those plant communities on the lithosols $(1,2$, and 3$)$. The Eragrostis pallens-Burkea africana Savanna did not differ $(p>0.05)$ from the latter plant communities. A negative correlation coefficient of $r=-0.6654$ was found between grass density and species density.

\section{Discussion}

\section{Percentage composition and percent-} age dry weight per ecological group

The generally high biomass and percentage composition of decreaser $17.1 \%$ (SD 8.57) and increaser I species $34.7 \%$ (SD 21.77) indicate a low grazing pressure in the Nylsvley Nature Reserve. These figures exclude data from the over-grazed Sporobolus ioclados-Acacia tortilis Savanna. This is a reflection of maintaining low numbers of wild animals $\left(\approx 0.29\right.$ animals ha $\left.{ }^{-1}\right)$ on the reserve over 2 decades. In comparison Smit and Rethman (1992) recorded 6.8\% decreasers and $18.3 \%$ increaser I species in long-term grazing trials (initiated in 1935/36) at low stocking densities of 0.25 animal units $\mathrm{ha}^{-1}$ and continuous grazing in Sourish Mixed Bushveld. This vegetation type is adjacent to Mixed Bushveld and has a similar climate. The grazing density of their trials may be comparable to the grazing regime in the Nylsvley Nature Reserve. Friedel (1988) recorded $8 \%$ decreasers after 35 years of light grazing in Combretum apiculatum veld, and $41 \%$ in Acacia tortilis veld protected from grazing in Mixed Bushveld.

The present degraded state of the Sporobolus ioclados-Acacia tortilis Savanna, dominated by increaser III grasses $(45.8 \%)$ is due mainly to the historic over-utilization by cattle ( $>20$ years ago) (Scholes and Walker 1993) and the long-term concentration of game in this plant community (casual observation). The herbaceous layer of this plant community was also in poor condition (Dörgeloh 1999).

\section{Species density and diversity}

The relatively large species densities found in the Nylsvley Nature Reserve can be attributed to the diversity of habitats, the climatic, geomorphological, and biogeographical history of the region. A low stocking density maintained over

Table 2. Species density, species diversity and mean grass density (SE is given in brackets) per plant community.

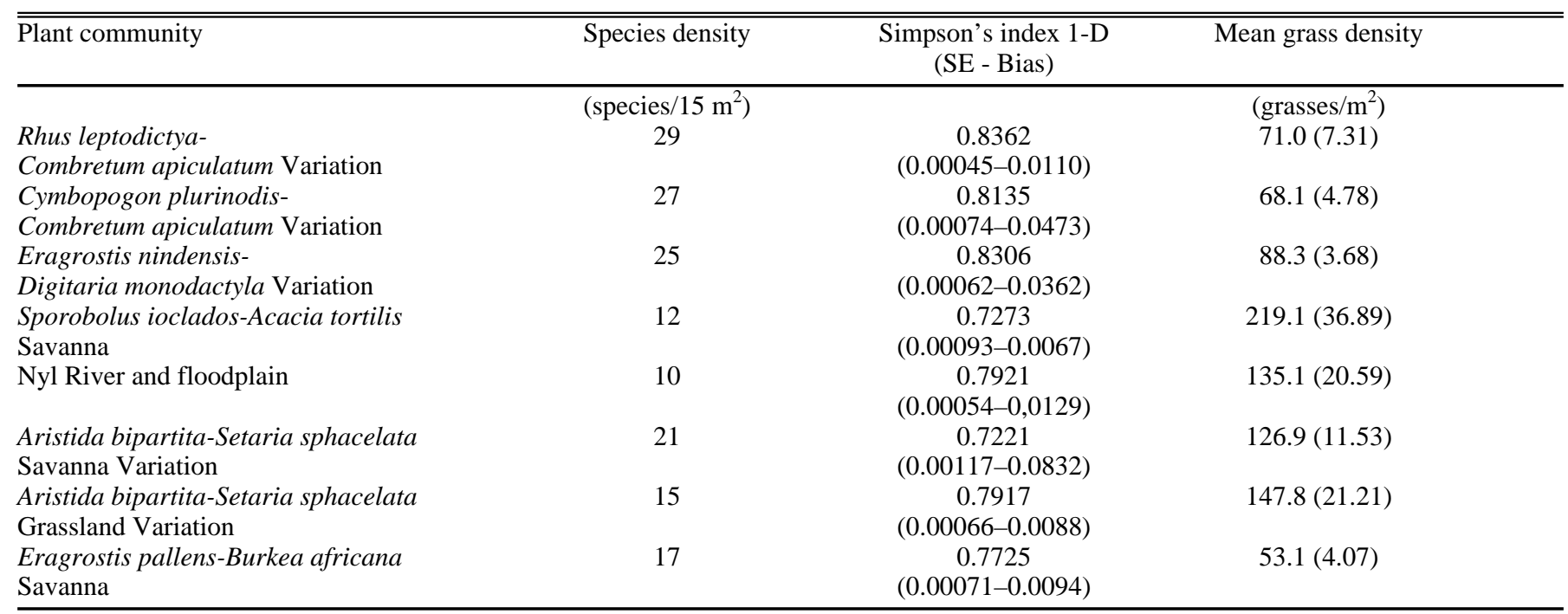


many year s and a rotational burning regime may have resulted in the evenness of species and therefore similar species diversities among plant communities. Below average rainfalls of $-18 \%$ in $1994 / 1995$ and $-23 \%$ in $1993 / 1994$, although still within the long term average rainfall of $623 \mathrm{~mm}$ (standard deviation of $134 \mathrm{~mm}$ ), did not affect the herbaceous diversity negatively.

Few studies have been conducted on the species composition in Mixed Bushveld (Lubke et al. 1983, Friedel 1988, Peel et al. 1991) or Sourish Mixed Bushveld (Smit and Rethman 1992). The methods used by these authors were mostly line transects which do not provide a measure of quantity (Friedel 1988). Lubke et al. (1983) estimated total plant diversity with a quadrat method only in the Burkea africanaEragrostis pallens Savanna. Data on species composition was generally used to assess range condition rendering it difficult to compare species density and diversity, or grass density.

\section{Grass density}

Eragrostis lehmanniana Nees (Lehmann's lovegrass) was the principal contributor to the very high grass densities in the Sporobolus ioclados-Acacia tortilis Savanna. In the Aristida bipartita -Setaria sphacelata plant communities (6 and 7) Cynodon dactylon Pers. (Couch grass) and I. afrum contributed to the high grass densities. The stoloniferous growth forms of dactylon and $I$. afrum may have led to an over-estimation of grass density.

The negative correlation between grass density and species density showed that over-grazing as found in the Sporobolus ioclados-Acacia tortilis Savanna, may have reduced species diversity. Under these over-utilized conditions, species richness decreases with an accompanying increase in dominance of a few species adapted to high grazing pressures. The abundance of grass species becomes unevenly distributed (Morrison et al. 1992) and the system becomes more simple in terms of biodiversity.

\section{Conclusion}

The high diversity of the herbaceous layer in the Nylsvley Nature Reserve is influenced by climatic, geomorphologi- cal and biogeographical factors and is a reflection of previous low animal stocking densities $\left(\approx 0.29\right.$ animals ha $\left.^{-1}\right)$ maintained over 2 decades. A long-term rotational burning programme where each plant community was burned at 2 to 3 year intervals probably also enhanced the herbaceous diversity. Slightly lower than average rainfalls did not affect the herbaceous diversity negatively. These results of the diversity of the herbaceous layer may serve as a benchmark for comparing range diversity over time and space within this vegetation type.

\section{Literature Cited}

Acocks, J.P.H. 1988. Veld types of South Africa. Mem. Bot. Surv. South Africa No. 57.

Barnes, D.L., J.J. Odendaal, and B.H. Beukes. 1982. Use of the dry-weight-rank method of botanical analysis in the eastern Transvaal highveld. Proc. Grassl. Soc. South Africa 17:79-82.

Ben-Shahar, R. 1991. Selectivity in large generalist herbivores: feeding patterns of African ungulates in a semi-arid habitat. Afr. J. Ecol. 29:302-315.

Causton, D.R. 1988. An introduction to vegetation analysis-principles, practice and interpretation. Unwin Hyman, London.

Coetzee, BJ, F. Van der Meulen, S. Zwanziger, $P$. Gonsalves, and P.J.Weisser. 1976. A phytosociological classification of the Nylsvley Nature Reserve. Bothalia 12:137-160.

Dörgeloh, W.G. 1997. Estimating sample size for a small-quadrat method of botanical survey for application in Mixed Bushveld. Afr. J. Range Forest. Sci. 14:87-89.

Dörgeloh, W.G. 1999. Assessment of veld conditions with multivariate techniques in mixed bushveld, So. Africa. Afr. J. Ecol. 36:194-201.

Dixon, P.M. 1993. The bootstrap and the jackknife: describing the precision of ecological indices. In: Scheiner, S.M. and Gurevitch, J. (eds.), Design and analysis of ecological experiments. Chapman \& Hall, New York.

Friedel, M.H. 1988. The development of veld assessment in the northern Transvaal savanna. II Mixed Bushveld. J. Grassl. Soc. South Africa 5: 55-63.

Frost, P.G.H. 1987. The regional landscape: Nylsvley in perspective. S.A. Nat. Sci..Programmes Rep. No. 133. Found. for Res. Dev., Pretoria.

Gibbs Russell, G.E., L. Watson, M. Koekemoer, L. Smook, N.P. Barker, H.M. Anderson, and M.J. Dallwitz.
1991. Grasses of southern Africa. Memoirs of the Bot. Surv. of South Africa No. 58. Nat. Bot. Gardens/Bot. Res. Inst., Pretoria.

Goldsmith, F.B. 1991. Vegetation monitoring. In: Goldsmith, B. (ed.), Monitoring for conservation and ecology. Chapman \& Hall, London.

Goldsmith, F.B., C.M. Harrison, and A.J. Morton. 1986. Description and analysis of vegetation. In: Moore, P.D. \& Chapman, S.B. (eds.), Methods in plant ecology. Blackwell Sci. Publ., London.

Holechek, J.L., R.D. Pieper, and C.H. Herbel. 1989. Range management: principles and practices. Prentice-Hall, Englewood Cliffs.

Kelly, R.D. and L. McNeill. 1980. Tests of two methods for determining yield and botanical composition. Pro. Grassl. Soc. South Africa 15:167-171.

Krebs, C.J. 1989. Ecological methodology. Haper Collins Publishers, New York.

Lubke, R.A., J.W. Morris, G.K. Theron and N. van Rooyen. 1983. Diversity, structure and pattern in Nylsvley vegetation. So Afr. J. Bot. 2:26-41.

Ludwig, J.A. and J.F. Reynolds. 1988. Statistical ecology: a primer on methods and computing. John Wiley \& Sons, New York.

Magurran, A.E. 1991. Ecological diversity and its measurement. Chapman \& Hall, London.

Morrison, M.L., B.G. Marcot, and R.W. Mannan. 1992. Wildlife-habitat relationships:concepts and applications. The University of Wisconsin Press, Madison.

O'Connor, T.G. 1991. Influence of rainfall and grazing on the compositional change of the herbaceous layer of a sandveld savanna. J. Grassl. Soc. South Africa 8:103-109.

Peel, M.J.S., D. Grossman, and N. van Rooyen. 1991. Determinants of herbaceous plant species composition on a number of ranches in the north-western Tranvaal. J. Grassl. Soc. So.. Afr. 8:99-102.

SAS Inc. 1990. [Version 6.08 (TS 404)]. SAS Institute Pty (Ltd), 1st floor Northring President Place, 100 Hood Ave, Rosebank, Rep. of So. Africa. 
Scholes, R.J. and B.H. Walker. 1993. An African savanna: synthesis of the Nylsvley study. Cambridge University Press, Cambridge.

Shackleton, C.M. 1992. Area and species selection by wild ungulates in coastal sour grasslands of Mkambati Game Reserve, Transkei, southern Africa. Afr. J. Ecol. 30:189-202.

Shukla, S.K. and P.R. Srivastava. 1992. Environmental wildlife impact analysis. Commonwealth Publ., New Delhi.

Smit, G.N. and N.F.G. Rethman. 1992. Inter-related floristic changes associated with different long-term grazing treatments in Sourish Mixed Bushveld. J. Grassl. Soc. South Africa 9:76-82.

Snyman, D.D., D. Grossman, and N.F.G. Rethman. 1990. Tekortkominge van die naateplant-metode en Dyksterhuis-verwante klassifikasiesisteme om veldtoestand in semi-ariede gebiede te bepaal. J. Grassl. Soc. So.. Afr. 7:273-276.

Tainton, N.M. 1984. The assessment of veld condition. In: Tainton, N.M. (ed.). Veld and pasture management in South Africa. Shuter \& Shooter, Pietermaritzburg. 't Mannetje, L. and K.P. Haydock. 1963. The dry-weight-rank method for the botanical analysis of pasture. J. Br. Grassl. Soc. 18:268-275.

Van Oudtshoorn, F.P. 1992. Guide to grasses of South Africa. Briza Publ., Arcadia.

Voisin, A. 1988. Grass productivity. Island Press, Washington, D.C.

Wratten, S.D. and G.L.A. Fry. 1980. Field and laboratory experiments in ecology. Edward Arnold, London. 